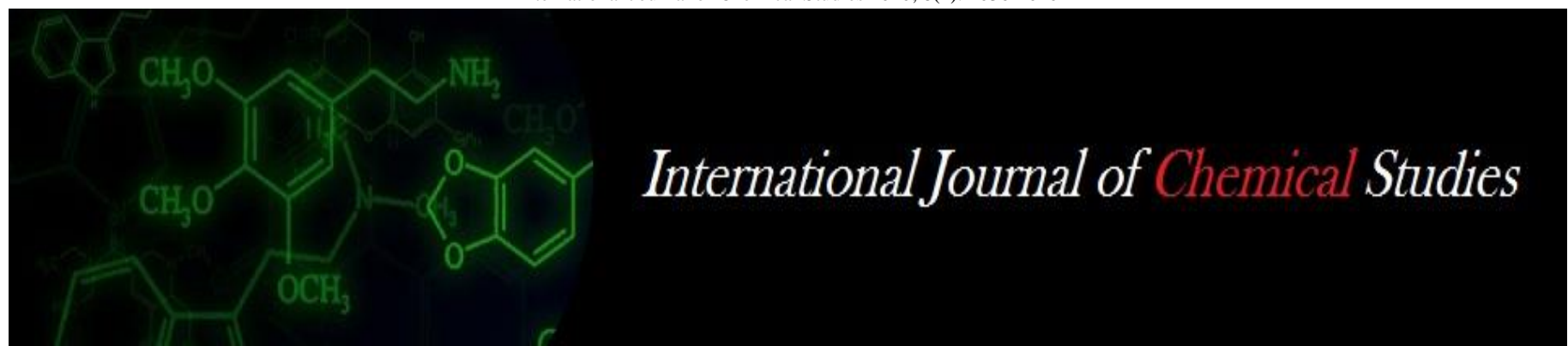

P-ISSN: 2349-8528

E-ISSN: 2321-4902

IJCS 2020; 8(1): 1036-1040

(C) 2020 IJCS

Received: 06-11-2019

Accepted: 10-12-2019

\section{Aditi Bharti}

Department of Horticulture,

Fruit \& Fruit Technology, Bihar

Agricultural University, Sabour,

Bhagalpur, Bihar, India

Kumari Karuna

Department of Horticulture,

Fruit \& Fruit Technology, Bihar

Agricultural University, Sabour,

Bhagalpur, Bihar, India

Hidayatullah Mir

Department of Horticulture,

Fruit \& Fruit Technology, Bihar Agricultural University, Sabour,

Bhagalpur, Bihar, India

\section{Shashikala}

Department of Horticulture,

Fruit \& Fruit Technology, Bihar

Agricultural University, Sabour,

Bhagalpur, Bihar, India

Shweta Kumari

Department of Horticulture,

Fruit \& Fruit Technology, Bihar Agricultural University, Sabour, Bhagalpur, Bihar, India
Corresponding Author: Aditi Bharti

Department of Horticulture,

Fruit \& Fruit Technology, Bihar

Agricultural University, Sabour,

Bhagalpur, Bihar, India

\section{Studies on pre-harvest fruit drop and improvement in physical parameters of Kinnow mandarin through exogenous application of plant growth regulators}

\author{
Aditi Bharti, Kumari Karuna, Hidayatullah Mir, Shashikala and Shweta \\ Kumari
}

DOI: https://doi.org/10.22271/chemi.2020.v8.i1n.8385

\begin{abstract}
An experiment was conducted in the department of Horticulture, Bihar Agricultural College, Sabour to show the effect of some plant growth regulators on fruit drop in Kinnow mandarin. The plant growth regulators viz. 2, 4-D (10 and $20 \mathrm{ppm}), \mathrm{GA} 3(25$ and $50 \mathrm{ppm})$ and NAA (10 and $20 \mathrm{ppm})$ were applied on $15^{\text {th }}$ October and $15^{\text {th }}$ November separately and in both the months to check the impact on pre-harvest fruit drop and physical parameters. Exogenous application of growth regulators 2, $4 \mathrm{D}(20 \mathrm{ppm})$ in both the months significantly decreased the pre-harvest fruit drop percentage leading to increase in total number of fruits per plant, fruit weight, length, width and juice percentage.
\end{abstract}

Keywords: Kinnow mandarin, plant growth regulators, fruit drop and yield

\section{Introduction}

Citrus, one of the most important fruit crop of sub-tropical region, is the world's leading tree fruit crop belonging to the family Rutaceae with chromosome number $2 n=18$. Citrus is native to tropical and subtropical region of Southeast Asia particularly, India and China. Kinnow is one of the important fruit crop among citrus species developed by H.B. Frost at Citrus Experiment Station, California in 1915 by crossing King (Citrus nobilis) and Willow Leaf (Citrus deliciosa). It was introduced in the year 1949 in Punjab. It is highly prized for its fruit qualities and is commercially cultivated due to its good yield, high processing quality, fresh consumption aromatic flavour and better adaptation to agro environmental condition of Punjab (Ahmed et al., 2006) ${ }^{[5]}$. Citrus occupies about $14.9 \%$ of the total land under various fruit crops in India. Currently, citrus is cultivated in an area of 1078 ('000HA) with total production of 11147 ('000MT) and average productivity is 10.3 metric tonnes in India (NHB, 2013-14).

Despite having so many qualities, fruit drop in Kinnow is a serious problem worldwide. Although fruit drop occurs in different waves, pre-harvest drop that occurs when fruits are half or $3 / 4$ mature is of main concern as it results in direct economic loss to the growers. Flowering, fruit set and its retention depends on several factors and hormonal regulation is one of them (Hucheche et al., 2012) ${ }^{[23]}$. Pre harvest drop is a very complex problem and mostly occurs due to formation of abscission layer. Tree drops its fruit when the concentration of auxins decreases and the concentration of abscissic acid (ABA) increases (Marinho et al., 2005) ${ }^{[24]}$ as the endogenous hormones and their balance play an important role in the mobilization of nutrients to the developing organ. The application of different plant growth regulators are recommended to reduce premature fruit drop by various workers across the world (Ashraf et al., 2012; Uniyal et al., 2015) ${ }^{[1,14]}$.

2, 4-Dichlorophenoxy acetic acid is a synthetic phenoxy compound, highly reputed as an abscission inhibitor of leaves and fruits, especially in fruit crops at sub lethal concentrations. Ashraf et al. (2013) ${ }^{[28]}$ have shown that it is possible to reduce pre-harvest drop of mature Kinnow fruits by applying 2, 4-D spray any time from three months before drop begins. Another advantage of this PGR is that fruits can be left on the tree for much longer period, even after normal harvest time, without considerable loss by fruit drop, and it also improves 
the quality of fruits by enhancing biochemical characteristics. Fruit size can be improved either by increasing carbohydrates availability to fruit or by increasing fruit sink strength. Application of synthetic auxins may act in these two ways, depending on the date of treatment (Patil et al., 2011; Jain et al., 2014) ${ }^{[20]}$.

Gibberellins include a large range of chemicals that are produced naturally within plants that helps in mobilization of food material used for growth of cell and helps in fruit retention and improving fruit quality (Gurung et al 2016; Rokaya et al 2016) ${ }^{[17,15]}$. NAA also inhibit the formation of abscission layer and reduces the fruit drop. Ghosh et al. (2012) ${ }^{[10]}$ found that NAA at 15 ppm is most effective in controlling fruit drop. Although some references are available in the literature and efforts have been made to control the fruit drop by exogenous application of growth regulators, there is no precise recommendation for the control of fruit drop in Kinnow mandarin.

Therefore, effective supply of plant growth regulators is necessary to produce high quality citrus fruits and control excessive citrus fruit drop which involves selection of appropriate plant growth regulators and their combination, rate and time of application.

Moreover, Kinnow mandarin has been recently introduced in the climatic conditions of Bihar, therefore the present experiments were conducted to study the control of excessive pre-harvest drop and improvement in fruit yield and quality by the application of 2, 4-D, GA, NAA and their combinations.

\section{Materials and Methods}

Bihar Agricultural University; Sabour, Bhagalpur is situated at longitude $87^{\circ} 2^{\prime} 42^{\prime \prime}$ East and latitude $25^{\circ} 15^{\prime} 40^{\prime \prime}$ North at an altitude of $46 \mathrm{~m}$ above mean sea level in the heart of vast Indo-Gangatic plains of North India. The climate of this place is sub-tropical characterized by hot desiccating summer, cold winter and moderate rainfall. May is the hottest month with an average maximum temperature of 35 to $39^{\circ} \mathrm{C}$. January is the coldest month of the year with mean minimum temperature varies from 5 to $10^{\circ} \mathrm{C}$. The average annual rainfall is $1380 \mathrm{~mm}$, precipitating mostly between mid-June to mid-October. Bihar Agricultural University, Sabour lays in Agro-climatic zone III A (NARP, Zone of the state) comprising 6 districts viz; Bhagalpur, Banka, Munger, Jamui, Lakhisarai and Sheikhpura of Bihar are having diverse type of topography and soil classes.

The meteorological data recorded during the experimentation period (2016-17) based on observations made at the meteorological observatory of the Bihar Agricultural University, Sabour are presented in Table 1.

Table 1: Weather conditions prevailing during experimentation (July 2016 to February 2017)

\begin{tabular}{|c|c|c|c|c|c|}
\hline \multirow{2}{*}{$\begin{array}{c}\text { Standard meteorological } \\
\text { weeks } 2016-17\end{array}$} & \multicolumn{2}{|c|}{ Temperature $\left({ }^{\circ} \mathrm{C}\right)$} & \multicolumn{2}{|c|}{ Relative Humidity (\%) } & \multirow{2}{*}{$\begin{array}{c}\text { Rain fall } \\
(\mathbf{m m})\end{array}$} \\
\hline & Max. & Min. & 07.00 A.M. & 02.00 P.M. & \\
\hline 27 & 30.8 & 25.3 & 93.0 & 84.0 & 204.1 \\
\hline 28 & 32.5 & 25.7 & 90.0 & 78.0 & 43.4 \\
\hline 29 & 31.5 & 25.5 & 89.0 & 84.0 & 40.9 \\
\hline 30 & 31.8 & 25.8 & 89.0 & 76.0 & 14.9 \\
\hline 31 & 33.1 & 25.6 & 87.0 & 74.0 & 1.4 \\
\hline 32 & 32.8 & 25.9 & 88.0 & 76.0 & 26.9 \\
\hline 33 & 35.0 & 25.8 & 86.0 & 80.0 & 35.1 \\
\hline 34 & 31.0 & 25.5 & 84.0 & 74.0 & 4.8 \\
\hline 35 & 33.4 & 26.2 & 89.0 & 74.0 & 2.2 \\
\hline 36 & 31.1 & 24.6 & 91.0 & 84.0 & 147.3 \\
\hline 37 & 31.7 & 25.5 & 89.0 & 76.0 & 11.4 \\
\hline 38 & 31.7 & 24.4 & 91.0 & 80.0 & 42.4 \\
\hline 39 & 30.1 & 23.7 & 89.0 & 83.0 & 119.6 \\
\hline 40 & 32.6 & 25.2 & 86.0 & 74.0 & 23.2 \\
\hline 41 & 30.9 & 23.9 & 92.0 & 77.0 & 8.6 \\
\hline 42 & 32.2 & 20.3 & 87.0 & 60.0 & 00.0 \\
\hline 43 & 31.0 & 19.6 & 90.0 & 62.0 & 00.0 \\
\hline 44 & 30.6 & 18.6 & 90.0 & 65.0 & 00.0 \\
\hline 45 & 30.6 & 16.2 & 86.0 & 61.0 & 00.0 \\
\hline 46 & 29.3 & 13.6 & 92.0 & 51.0 & 00.0 \\
\hline 47 & 27.8 & 11.9 & 92.0 & 48.0 & 00.0 \\
\hline 48 & 27.1 & 12.6 & 92.0 & 62.0 & 00.0 \\
\hline 49 & 23.0 & 11.7 & 96.0 & 72.0 & 00.0 \\
\hline 50 & 18.7 & 8.0 & 97.0 & 75.0 & 00.0 \\
\hline 51 & 23.3 & 8.2 & 95.0 & 59.0 & 00.0 \\
\hline 52 & 23.0 & 10.0 & 96.0 & 74.0 & 00.0 \\
\hline 1 & 20.9 & 8.6 & 98.0 & 76.0 & 00.0 \\
\hline 2 & 21.3 & 8.0 & 96.0 & 61.0 & 00.0 \\
\hline 3 & 22.7 & 6.0 & 93.0 & 48.0 & 00.0 \\
\hline 4 & 25.1 & 8.2 & 91.0 & 59.0 & 12.4 \\
\hline 5 & 22.2 & 8.0 & 98.0 & 63.0 & 00.0 \\
\hline 6 & 25.8 & 7.9 & 89.0 & 51.0 & 00.0 \\
\hline 7 & 26.6 & 9.5 & 95.0 & 46.0 & 00.0 \\
\hline 8 & 28.4 & 11.5 & 86.0 & 44.0 & 00.0 \\
\hline 9 & 29.2 & 10.5 & 83.0 & 36.0 & 00.0 \\
\hline
\end{tabular}




\section{Experimental details}

The experiment was carried out in high density orchard of Kinnow mandarin of Bihar Agricultural College, Sabour, Bhagalpur. Six years old 57 trees of Kinnow mandarin of uniform size and age were selected for this experiment. The selected tress were tagged and given uniform cultural practices throughout the period of study. On the selected trees 2,4-D (10 and $20 \mathrm{ppm}), \mathrm{GA} 3$ (25 and $50 \mathrm{ppm}$ ) and NAA (10 and $20 \mathrm{ppm})$ were sprayed on $15^{\text {th }}$ October, $15^{\text {th }}$ November and in both the months to check the effect on pre-harvest fruit drop and physical properties of the fruits. The experiment consisted of 19 treatments including control with three replications and single tree was taken as an experimental unit. Number of fruits was counted on each selected tree before the start of experiment. The fruit drop from the selected trees was counted at 7 days interval starting from $15^{\text {th }}$ October and up to $15^{\text {th }}$ November and fruit drop percentage was calculated:

\section{Total no of dropped fruits}

\section{Fruit drop \% $\%$}

Total no of fruits before application

Yield per tree was calculated at the time of harvesting. Fruit length and width of 10 fruits/tree and fruit weight was also calculated.

\section{Statistical analysis and interpretation of data}

The experimental data was subjected to statistical analysis in order to find out which of the treatments showed significant variation in different parameters/attributes studied under investigation. The technique of analysis of variance (ANOVA) for randomized block design (RBD) was adopted as suggested by Panse and Sukhatme (1967).

\section{Results and Discussion}

The exogenous application of plant growth regulators significantly reduced the pre-harvest fruit drop as compared to control $(30.87 \%)$. The minimum fruit drop (12.87\%) was found in the trees sprayed with 2,4-D $20 \mathrm{ppm}$ on $15^{\text {th }}$ October $+15^{\text {th }}$ November followed by NAA 20 ppm (16\%) sprayed on $15^{\text {th }}$ October $+15^{\text {th }}$ November which was at par with $2,4-\mathrm{D} 10$ ppm $(16.68 \%)$ sprayed on $15^{\text {th }}$ October $+15^{\text {th }}$ November. Among the GA treatments the minimum fruit drop (22.17\%) was observed in $\mathrm{T}_{12}$ when trees were sprayed with GA 50 ppm on October $+15^{\text {th }}$ November. Reduction in fruit drop percentage favours the hypothesis of Jahromi et al. (2013) ${ }^{[11]}$, who demonstrated a relationship between auxin and fruit drop in local tangerine. He reported the maximum reduction in total fruit drop with $20 \mathrm{ppm} \mathrm{2,} \mathrm{4-D.} \mathrm{The} \mathrm{present} \mathrm{findings} \mathrm{are}$ also in agreement with the results of Nawaz et al. (2008) [37] and Ashraf et al. (2013) ${ }^{[28]}$. The fruit drop in citrus may be attributed to formation of abscission layer at the stem point (Lal et al., 2015) ${ }^{[16]}$. Keeping in view the above results it can safely be recommended to growers that 2, 4-D at 10 and 20 ppm can be sprayed to control pre-harvest drop.

All the treatments improved the yield significantly over control (19 fruits/tree) through exogenous application of plant growth regulators. The maximum fruit yield (69 fruits/ tree) was obtained from trees sprayed with $20 \mathrm{ppm} 2,4-\mathrm{D}$ on $15^{\text {th }}$ October $+15^{\text {th }}$ November, followed by NAA at $20 \mathrm{ppm}$ ( 55.68 fruits / plant) sprayed on $15^{\text {th }}$ October $+15^{\text {th }}$ November which was at par with 2,4-D at 10 ppm (55 number of fruits/ tree) sprayed on $15^{\text {th }}$ October $+15^{\text {th }}$ November. The present finding are also in agreement with the results of Jain et al. (2014) ${ }^{[20]}$, Yaser et al. (2016) ${ }^{[22]}$ and Bhatt et al. (2017) ${ }^{[8]}$ who revealed that application of 2, $4 \mathrm{D}$ gave superior fruits with highest number of fruits per plant.

The foliar application of 2, 4-D at $20 \mathrm{ppm}$ sprayed on $15^{\text {th }}$ 0ctober $+15^{\text {th }}$ November significantly improved fruit weight $(194.67 \mathrm{~g})$, followed by treatment of NAA at $20 \mathrm{ppm}$ $(188.33 \mathrm{~g})$ sprayed on $15^{\text {th }}$ October $+15^{\text {th }}$ November. The minimum fruit weight was recorded under control (159.33g). The findings are in agreement with the reports by Ashraf et al. (2013) ${ }^{[28]}$ who reported that foliar application of 2, 4-D significantly increases the fruit weight. The maximum fruit width $(79.80 \mathrm{~mm})$ was observed with $2,4-\mathrm{D}$ at $20 \mathrm{ppm}$ sprayed on $15^{\text {th }}$ October $+15^{\text {th }}$ November. Improvement in physical parameters of fruit in present experiment with exogenous application of 2, 4-D may be attributed to accelerated fruit growth and finally fruit size by increasing cell enlargement. Agusti et al. (2002) ${ }^{[26]}$ suggested that, the role of plant growth hormones as " mobilizers" of the nutrients from other parts of the plant to the actively growing metabolic "sinks" i.e. fruits which may also be an important factor contributing to improved size. Ghosh et al. (2012) ${ }^{[10]}$ reported increase in fruit size in Sweet orange by spraying auxins at the rate of $15 \mathrm{ppm}$. Auxin is also known to affect the permeability of cell wall leading to uptake of water and expansion of cells, resulting in cell elongation. Auxin also induces and promotes the growth substances which may be pre-requisite for auxin induced fruit growth. The possible explanation for improved fruit quality under auxin treatment may be delay in fruit maturity that allows fruits to remain on tree for a longer period during which they can accumulate more food reserves and water within them (Singh et al., 1986) [27]. NAA at the rate of $20 \mathrm{ppm}$ produced maximum fruit length and breadth (Uniyal et al., 2015) ${ }^{[14]}$. Yaser et al. (2016) ${ }^{[22]}$ found that 2, 4-D $(0.002 \%)$ improved the juice content of Thompson Naval orange. After application of auxin, there is synthesis of photosynthates by leaves due to which stimulation of cell expansion occurs, especially of juice vesicle. This expansion may increase the vesicle capacity for juice accumulation (Agusti et al., 1995) ${ }^{[4]}$

Table 2: Effect of plant growth regulators on pre-harvest fruit drop and yield

\begin{tabular}{|c|c|c|c|}
\hline Treatments & Date of spray & Fruit drop (\%) & Yield (no. of fruits/plant) \\
\hline $\mathbf{T}_{1}-2,4-\mathrm{D}(10 \mathrm{ppm})$ & $15-\mathrm{OCT}$ & 18.73 & 43.67 \\
\hline $\mathbf{T}_{\mathbf{2}}-2,4-\mathrm{D}(10 \mathrm{ppm})$ & $15-\mathrm{NOV}$ & 19.90 & 36.33 \\
\hline $\mathrm{T}_{3}-2,4-\mathrm{D}(10 \mathrm{ppm})$ & $15 \mathrm{OCT}+15 \mathrm{NOV}$ & 16.68 & 55 \\
\hline $\mathrm{T}_{4}-2,4-\mathrm{D}(20 \mathrm{ppm})$ & $15-\mathrm{OCT}$ & 23.01 & 36.00 \\
\hline $\mathrm{T}_{5}-2,4-\mathrm{D}(20 \mathrm{ppm})$ & $15-\mathrm{NOV}$ & 17.63 & 44.33 \\
\hline $\mathrm{T}_{6}-2,4-\mathrm{D}(20 \mathrm{ppm})$ & $15 \mathrm{OCT}+15 \mathrm{NOV}$ & 12.87 & 69.00 \\
\hline $\mathrm{T}_{7}-\mathrm{GA} 3(25 \mathrm{ppm})$ & $15-\mathrm{OCT}$ & 22.47 & 27.00 \\
\hline $\mathrm{T}_{8}-\mathrm{GA3}(25 \mathrm{ppm})$ & $15-\mathrm{NOV}$ & 27.00 & 28.33 \\
\hline $\mathrm{T}_{9}-\mathrm{GA} 3(25 \mathrm{ppm})$ & 15 OCT $+15 \mathrm{NOV}$ & 26.33 & 23.33 \\
\hline $\mathrm{T}_{10}-\mathrm{GA} 3(50 \mathrm{ppm})$ & $15-\mathrm{OCT}$ & 25.05 & 26.67 \\
\hline
\end{tabular}




\begin{tabular}{|c|c|c|c|}
\hline $\mathrm{T}_{11}-\mathrm{GA3}(50 \mathrm{ppm})$ & 15-NOV & 26.11 & 35.00 \\
\hline $\mathrm{T}_{12}-\mathrm{GA3}(50 \mathrm{ppm})$ & $15 \mathrm{OCT}+15 \mathrm{NOV}$ & 22.17 & 27.00 \\
\hline $\mathrm{T}_{13}-\mathrm{NAA}(10 \mathrm{ppm})$ & $15-\mathrm{OCT}$ & 21.53 & 24.00 \\
\hline $\mathrm{T}_{14}-\mathrm{NAA}(10 \mathrm{ppm})$ & $15-\mathrm{NOV}$ & 21.58 & 41.67 \\
\hline $\mathrm{T}_{15}-\mathrm{NAA}(10 \mathrm{ppm})$ & $15 \mathrm{OCT}+15 \mathrm{NOV}$ & 18.23 & 39.00 \\
\hline $\mathrm{T}_{16}-\mathrm{NAA}(20 \mathrm{ppm})$ & $15-\mathrm{OCT}$ & 21.05 & 40.33 \\
\hline $\mathrm{T}_{17}-\mathrm{NAA}(20 \mathrm{ppm})$ & $15-\mathrm{NOV}$ & 19.63 & 55.68 \\
\hline $\mathrm{T}_{18}-\mathrm{NAA}(20 \mathrm{ppm})$ & $15 \mathrm{OCT}+15 \mathrm{NOV}$ & 16.00 & 19.33 \\
\hline $\mathrm{T}_{19}(\mathrm{control})$ & & 30.87 & 2.08 \\
\hline $\mathrm{CD}(\mathrm{p}=0.5)$ & & 2.9 & 0.72 \\
\hline $\mathrm{SEM}( \pm)$ & & 1.03 & \\
\hline
\end{tabular}

Table 3: Effect of plant growth regulators on physical parameters

\begin{tabular}{|c|c|c|c|c|c|c|}
\hline Treatments & Date of spray & Fruit weight (gm) & $\begin{array}{c}\text { Fruit breadth } \\
(\mathrm{mm})\end{array}$ & Fruit length(mm) & Juice \% & Juice/pomace \\
\hline $\mathbf{T}_{\mathbf{1}}-2,4-\mathrm{D}(10 \mathrm{ppm})$ & 15-Oct & 175.00 & 72.43 & 63.46 & 42.39 & 1.05 \\
\hline $\mathbf{T}_{\mathbf{2}}-2,4-\mathrm{D}(10 \mathrm{ppm})$ & 15-Nov & 171.33 & 73.00 & 67.97 & 41.87 & 1.21 \\
\hline $\mathrm{T}_{3}-2,4-\mathrm{D}(10 \mathrm{ppm})$ & $15 \mathrm{OCT}+15 \mathrm{NOV}$ & 183.33 & 74.05 & 69.39 & 45.74 & 1.35 \\
\hline $\mathrm{T}_{4}-2,4-\mathrm{D}(20 \mathrm{ppm})$ & 15-Oct & 180.00 & 70.40 & 67.53 & 45.13 & 1.25 \\
\hline $\mathrm{T}_{5}-2,4-\mathrm{D}(20 \mathrm{ppm})$ & 15-Nov & 178.00 & 72.53 & 66.13 & 43.90 & 1.2 \\
\hline $\mathrm{T}_{6}-2,4-\mathrm{D}(20 \mathrm{ppm})$ & $15 \mathrm{OCT}+15 \mathrm{NOV}$ & 194.67 & 79.80 & 74.35 & 51.52 & 1.49 \\
\hline $\mathrm{T}_{7}-\mathrm{GA} 3(25 \mathrm{ppm})$ & 15 -Oct & 166.67 & 68.04 & 58.73 & 41.46 & 1 \\
\hline $\mathrm{T}_{8}-\mathrm{GA} 3(25 \mathrm{ppm})$ & $15-\mathrm{Nov}$ & 168.17 & 69.62 & 58.81 & 41.27 & 1.05 \\
\hline $\mathrm{T}_{9}-\mathrm{GA} 3(25 \mathrm{ppm})$ & $15 \mathrm{OCT}+15 \mathrm{NOV}$ & 170.00 & 67.46 & 59.00 & 41.25 & 0.99 \\
\hline $\mathrm{T}_{10}-\mathrm{GA} 3(50 \mathrm{ppm})$ & 15 -Oct & 166.33 & 69.17 & 58.55 & 42.00 & 0.94 \\
\hline $\mathrm{T}_{11}-\mathrm{GA} 3(50 \mathrm{ppm})$ & 15-Nov & 168.67 & 66.44 & 59.07 & 42.04 & 0.9 \\
\hline $\mathrm{T}_{12}-\mathrm{GA} 3(50 \mathrm{ppm})$ & $15 \mathrm{OCT}+15 \mathrm{NOV}$ & 176.00 & 68.98 & 61.53 & 44.26 & 1.22 \\
\hline $\mathrm{T}_{13}-\mathrm{NAA}(10 \mathrm{ppm})$ & 15 -Oct & 165.00 & 70.59 & 66.27 & 42.41 & 1.2 \\
\hline $\mathrm{T}_{14}-\mathrm{NAA}(10 \mathrm{ppm})$ & $15-\mathrm{Nov}$ & 165.00 & 73.01 & 63.16 & 44.39 & 1.31 \\
\hline $\mathrm{T}_{15}-\mathrm{NAA}(10 \mathrm{ppm})$ & $15 \mathrm{OCT}+15 \mathrm{NOV}$ & 178.50 & 74.33 & 68.12 & 45.74 & 1.36 \\
\hline $\mathrm{T}_{16}-\mathrm{NAA}(20 \mathrm{ppm})$ & 15 -Oct & 174.50 & 73.83 & 65.73 & 43.83 & 1.39 \\
\hline $\mathrm{T}_{17}-\mathrm{NAA}(20 \mathrm{ppm})$ & 15-Nov & 176.00 & 72.88 & 68.48 & 43.72 & 1.04 \\
\hline $\mathrm{T}_{18}-\mathrm{NAA}(20 \mathrm{ppm})$ & $15 \mathrm{OCT}+15 \mathrm{NOV}$ & 188.33 & 77.61 & 72.39 & 48.99 & 1.45 \\
\hline $\mathrm{T}_{19}$ (control) & & 159.33 & 59.25 & 53.69 & 40.59 & 0.85 \\
\hline $\mathrm{CD}(\mathrm{p}=0.5)$ & & 4.2 & 3.1 & 4.3 & 2.3 & 0.13 \\
\hline $\operatorname{SEM}( \pm)$ & & 1.4 & 1.09 & 1.5 & 0.81 & 0.063 \\
\hline
\end{tabular}

\section{Conclusion}

2,4- Dichlorophenoxy acetic acid showed significant reduction in fruit drop and improving physical parameters of Kinnow mandarin when sprayed on $15^{\text {th }}$ October $+15^{\text {th }}$ November at the rate of $20 \mathrm{ppm}$ as compared to different concentration of other growth regulators. Thus, 2, 4-D could be applied through exogenous application to increase fruit yield under conditions that favours fruit drop and its full potential could be exploited if applied in required quantity and at appropriate growth stage.

\section{References}

1. Ashraf MY, Yaqub M, Akhtar J, Khan MA, Eb ert, G. Control of excessive fruit drop and improvement in yield and juice quality of Kinnow through nutrient management. Pak. J Bot. 2012; 44:259-265.

2. Ahmed W, Ziaf K, Nawaz MA, Saleem BA. Studies on combining ability of citrus hybrids with commercial indigenous cultivars. Pak. J Bot. 2007; 39(1):47-55.

3. Almeida I, Leite IM, Rodrigues JD, Ono EO. Application of plant growth regulators at pre-harvest for fruit development of 'PERA' oranges. Braz. Arch. Bio. Technol. 2004; 47(7):658-662.

4. Agusti M, Almela V, Aznar Juan M, Veres V. Recent findings on the mechanism of action of the synthesis auxins used to improve fruit size of citrus. Proc. Int. Soc. Citriculture. 1995; 2:922-928.

5. Ahmed W, Pervez MA, Amjad M, Khalid M, Ayyub CM, Nawaz MA. Effect of stonic combination on the growth and ysield of Kinnow mandarin. Pak. J Bot. 2006; 38(3):603-612.

6. Bose TK, Hussain T, Mitra SK, Roy A. Control of pre mature fruit drop in mandarin orange. Haryana J. Hort. Sci. 1988; 17(3-4):140-143.

7. Bhati AS, Kanwar J, Naruka IS, Tiwari R, Gallani R, Singh O. An international journal of life science. 2016; 11(4):2665-2668

8. Bhatt BB, Singh KK, Rawat SS. Influence of Foliar Application of Bio-Regulators and Nutrients on the Fruit Quality of Lemon (Citrus limon Burma.) Cv. Pant Lemon-1. Int. J Curr. Microbial. App. sci. 2017; 6(4):2451-2458.

9. Bons HK, Kaur N, Rattanpal HS. Quality and quantity improvement of citrus: role of plant growth regulators. International journal of Agriculture, Environment and Biotechnology. 2015; 8(2):433-447.

10. Ghosh SN, Bera B, Roy S. Influnence of plant growth regulators on fruit production of sweet orange. Journal of crop and weed. 2012; 8(2):83-85.

11. Jahromi NSM, Kholdebarin B, Rajaei H. Fruit drop prevention in local tangerine by growth regulators in response to application time. Indian J Hort. 2013; 70(7):491-495.

12. Mir H, Itoo H. Effect of foliar spray of 2, 4-D and frequency of application on preharvest fruit drop, yield and quality in Kinnow mandarin. Indian journal of ecology. 2017; 44(3):534-538.

13. Nirgude V, Kumari K, Mankar A, Kumar V, Spandana M. Response of fertigation on phenol-physiological status 
of Citrus sinensis Osbeck cv. Mosambi under high density planting. Journal of applied and natural science. 2016; 8(3):1306-1311.

14. Uniyal S, Misra KK. Effect of plant growth regulators on fruit drop and quality of Bael under Tarai conditions of Uttarakhand. Indian J Hort. 2015; 72(1):126-129.

15. Rokaya PR, Baral DR, Gautam DM, Shrestha AK, Paudyal PR. Effect of pre- harvest application of Gibberellic acid on Fruit Quality and shelf life of Kinnow mandarin. American journal of plant science. 2016; 7:1033-1039.

16. Lal D, Tripathi VK, Kumar S, Nayyer MA. Effect of preharvest application of gibberalic acid, NAA and calcium nitrate on fruit drop and storage quality of Kinnow mandarin. Res. Environ. Life Sci. 2015; 8(4):561-612.

17. Gurung S, Mahato SK, Suresh CP, Chetri B. Impact of Foliar Application of Growth Regulators and Micronutrients on the Performance of Darjeeling Mandarin American journal of Experimental Agriculture. 2016; 12(4):1-7.

18. Patil NB, Shedame MB, Ingle SH. Effect of plant growth regulators and fungicide on pre- harvest fruit drop in Nagpur mandarin. Asian Journal of Bioscience. 2010; $6(1)$.

19. Jain MC, Choudhary HD, Sharma MK, Bhatnagar P, Gupta NK. Effect and economic feasibility of plant growth regulators on Yield of 'Nagpur mandarin'. International Journal of Advanced Biological Research. 2015; 5(1):1-4.

20. Jain MC, Choudhary HD, Sharma MK, Bhim S. Yield and quality attributes of Nagpur Mandarin as affected by use of different plant growth regulators. Environment \& Ecology. 2014; 32(3A):1141-1145.

21. Singh SR, Wangchu L, Singh B, Hazarika BN, Pandey AK. Indian J Agric Res. 2017; 51(2):167-172.

22. Yaser MA, Ahmad W, Ahmad S, Khan MM. Role of growth regulators on preharvest fruit drop, yield and quality in Kinnow mandarin. Pak. J Bot. 2016; 40(5):1971-1981

23. Hucheche CD, Moreira CS, Sarries GA. Study of preharvest drop in orange. Cv. Natal. Revista-deAgricultura Piracicaba. 2012; 71:361-78.

24. Marinho CS, Olivera L, Serrano JC, Carvalho J. Effect of Gibberellic acid fungicide on post- bloom fruit drop in Tahiti lime. Laranja. 2005; 26(1):47-57.

25. Nawaz MA, Ahmad W, Ahmad S, Khan MM. Role of growth regulators on preharvest fruit drop, yield and quality in Kinnow mandarin. Pak. J Bot. 2008; 40(5):1971-1981.

26. Agusti M, Almela V, Aznar Juan M, Veres V. Recent findings on the mechanism of action of the synthesis auxins used to improve fruit size of citrus. Proc Int. Soc. Citriculture. 2002; 2:922-928.

27. Singh IP, Singh BP, Singh SP. Effect of 2, 4-D and GA3 on fruit drop and quality of mango cv. Samar Bahist Chausa. Haryana Hort. Sci. 1986b; 15(1-2).

28. Ashraf MY, Yaqub M, Akhtar J, Khan MA, Ebert G. Control of excessive fruit drop and improvement in yield and juice quality of Kinnow through nutrient management. Pak. J Bot. 2013; 44:259-265. 